\title{
'Coho' Red Raspberry
}

\author{
Chad E. Finn ${ }^{1}$ and Francis J. Lawrence ${ }^{2}$
}

U.S. Department of Agriculture-Agricultural Research Service, Horticultural Crops Research Laboratory, Northwest Center for Small Fruit Research, Corvallis, OR 97330

\section{Brian Yorgey ${ }^{3}$ \\ Department of Food Science, Oregon State University, Corvallis, OR 97331 \\ Bernadine C. Strik ${ }^{4}$ \\ Department of Horticulture, Oregon State University, Corvallis, OR 97331}

Additional index words. Rubus idaeus, fruit breeding

'Coho' (Fig. 1) is a new floricane fruiting red raspberry (Rubus idaeus L.) from the U.S. Dept. of Agriculture-Agricultural Research Service (USDA-ARS) breeding program in Corvallis, Ore., released in cooperation with the Oregon State Agricultural Experiment Station, the Washington State Univ. Agricultural Research Center, and the Idaho Agricultural Experiment Station. 'Coho' is high yielding and late-ripening, and produces large, bright red, very firm fruit that separate easily from the receptacle. The cultivar is best suited for fresh markets, although it has been reported to be excellent when individually quick frozen (IQF; commercial processor, personal communication). The 'Coho' ripening season is later than 'Tulameen' and slightly earlier than 'Kitsilano' and it produces larger fruit than the latter.

'Coho' is named after the salmon (Oncorhynchus kisutch Walbaum) that is renowned for its brilliant red body coloration and late spawning runs.

\section{Origin}

'Coho' was selected in 1985 from a cross between 'Lewis' and ORUS 520-48 and tested as ORUS 958-10 (Fig. 2). 'Lewis' was released in 1998 as a large-fruited, high-quality, late-season raspberry (Finn et al., 2001). ORUS 520-48 has a diverse background, including the United Kingdom release 'Malling Promise', Pacific Northwest cultivars Canby, Willamette, and Washington, and a selection made from a population of

Received for publication 15 Sept. 2000. Accepted for publication 6 Apr. 2001. This research was partially funded by the Oregon Raspberry and Blackberry Commission. We gratefully acknowledge the assistance of Kirsten Wennstrom, Derek Peacock, Connie Pace and Gina Koskela in 'Coho's evaluation and Robert Martin's USDA-ARS lab for their use of thermotherapy to free 'Coho' of known viruses and for determining its virus negative status. The cost of publishing this paper was defrayed in part by the payment of page charges. Under postal regulations, this paper therefore must be hereby marked advertisement solely to indicate this fact. ${ }^{1}$ Research Geneticist.

${ }^{2}$ Research Geneticist (retired)

${ }^{3}$ Senior Research Assistant.

${ }^{4}$ Professor. native $R$. idaeus var. strigosus (Michaux) Maxim growing on Mt. Mitchell, N.C. To the best of our knowledge, 'Coho' and 'Lewis' (Finn et al., 2001) are the first two cultivars that have this Mt. Mitchell background, and they add to the number of founding clone or selections of $R$. idaeus var. strigosus that have been used in raspberry breeding (Dale et al., 1989).

'Coho' has been tested in Aurora, Ore., and in grower fields in Washington and Oregon. The most thorough testing was done at the North Willamette Research and Extension Center of Oregon State Univ. (Aurora, Ore.). The planting at Aurora was established in 1994 and arranged in a randomized complete-block design, with three, three-plant replications ( $0.9 \mathrm{~m}$ between plants) used for measuring fresh fruit characteristics, harvest season, yield, and fruit weight. During the

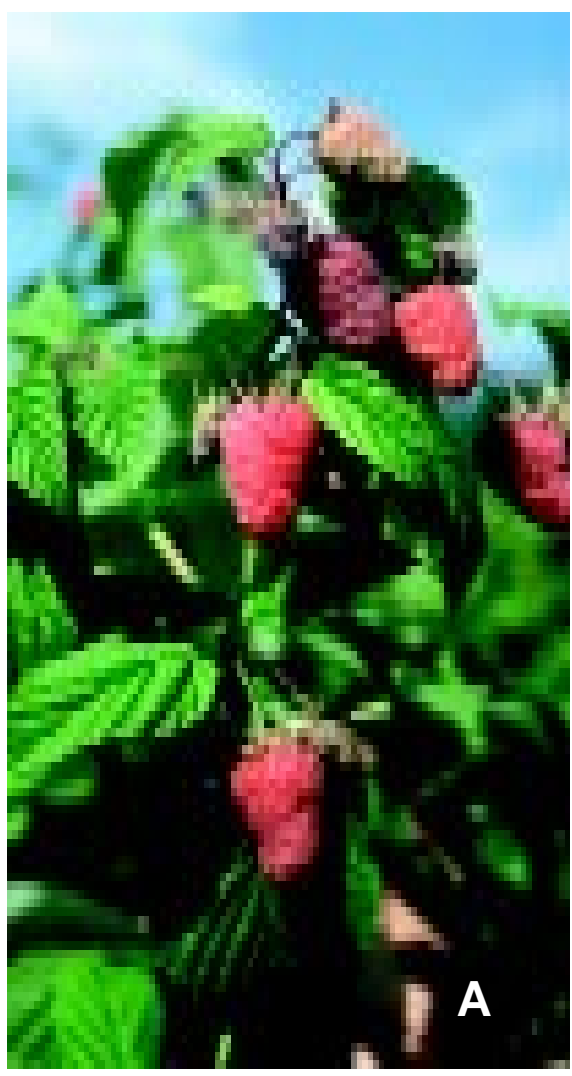

\section{Description and performance}

There was a significant cultivar $\times$ year interaction for yield and fruit weight (Table 1). Over 2 years, the yield of 'Coho' was similar to 'Comox' and 'Meeker' and greater than the other cultivars (Table 1). 'Meeker' is the most widely grown cultivar in the Pacific Northwest (Moore and Daubeny, 1993). 'Comox', 'Tulameen', and 'Kitsilano' have been previously noted for high yields (Daubeny, 1987, 1999; Daubeny and Anderson, 1991). 'Coho' fruit weighed less than those of 'Tulameen' but more than 'Malahat', which is considered large fruited (Daubeny,

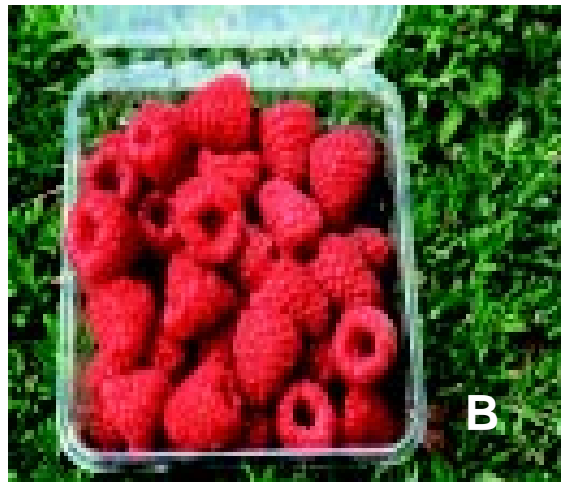

Fig. 1. 'Coho' red raspberry. A) fruiting plant, B) harvested fruit. 


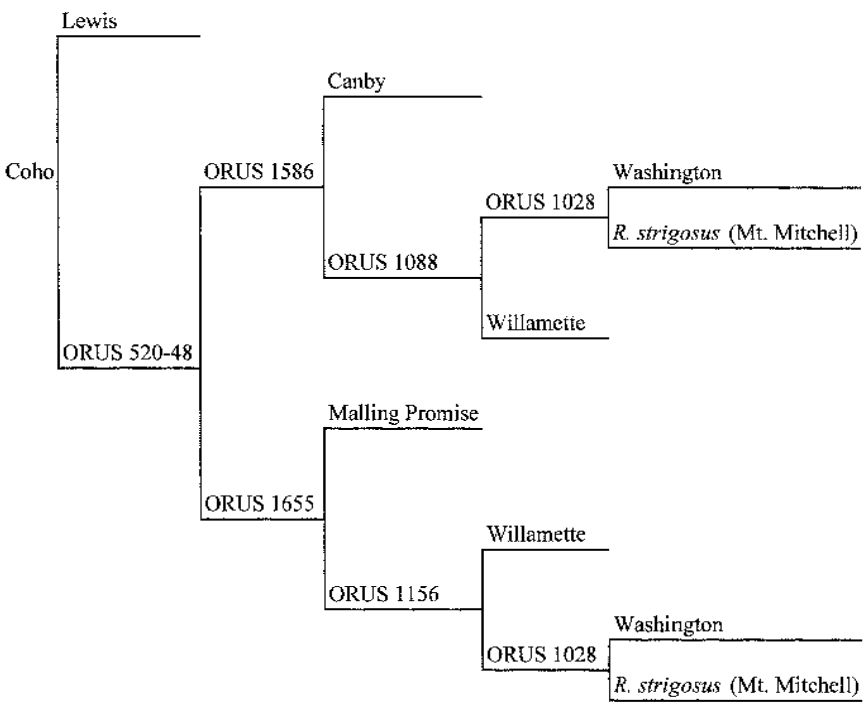

Fig. 2. 'Coho' red raspberry pedigree.

Table 1. Fruit weight and yield in 1996, 1997 and mean of both years for nine red raspberry cultivars planted in 1994 at OSU-North Willamette Research and Extension Center, Aurora, Ore.

\begin{tabular}{|c|c|c|c|c|c|c|}
\hline \multirow[b]{2}{*}{ Cultivar } & \multicolumn{3}{|c|}{ Fruit wt $(\mathrm{g})$} & \multicolumn{3}{|c|}{ Yield $\left(\mathrm{kg} \cdot \mathrm{ha}^{-1}\right)$} \\
\hline & 1996 & 1997 & 1996-97 & 1996 & 1997 & 1996-97 \\
\hline$\overline{\text { Coho }}$ & $2.48 \mathrm{de}$ & $4.31 \mathrm{~b}$ & $3.40 \mathrm{bc}$ & $20269 \mathrm{a}$ & $13245 \mathrm{ab}$ & $16757 \mathrm{a}$ \\
\hline Comox & $2.96 \mathrm{~b}-\mathrm{d}$ & $3.72 \mathrm{c}-\mathrm{e}$ & $3.34 \mathrm{bc}$ & $17276 a b$ & $14625 \mathrm{ab}$ & $15951 \mathrm{ab}$ \\
\hline Meeker & $2.68 \mathrm{~cd}$ & $3.47 \mathrm{df}$ & $3.08 \mathrm{c}$ & $11162 \mathrm{c}$ & $16544 \mathrm{a}$ & $13853 \mathrm{a}-\mathrm{c}$ \\
\hline Chilliwack & $3.11 \mathrm{bc}$ & $3.86 \mathrm{~cd}$ & $3.49 \mathrm{~b}$ & $16592 \mathrm{ab}$ & $10121 b c$ & $13356 \mathrm{bc}$ \\
\hline Chilcotin & $3.04 \mathrm{bc}$ & $4.02 \mathrm{bc}$ & $3.53 \mathrm{~b}$ & $9582 \mathrm{c}$ & $16382 \mathrm{a}$ & $12982 b c$ \\
\hline Willamette & $2.76 \mathrm{~b}-\mathrm{d}$ & $3.68 \mathrm{~d}-\mathrm{e}$ & $3.22 \mathrm{bc}$ & $11365 \mathrm{c}$ & $14272 a b$ & $12818 b c$ \\
\hline Kitsilano & $2.03 \mathrm{e}$ & $3.29 \mathrm{f}$ & $2.66 \mathrm{~d}$ & $14095 \mathrm{bc}$ & $11461 \mathrm{bc}$ & $12778 \mathrm{bc}$ \\
\hline Tulameen & $3.28 \mathrm{ab}$ & $4.79 \mathrm{a}$ & $4.04 \mathrm{a}$ & $13332 \mathrm{bc}$ & $11643 \mathrm{bc}$ & $12488 \mathrm{c}$ \\
\hline Malahat & $3.70 \mathrm{a}$ & $3.20 \mathrm{f}$ & $3.45 \mathrm{c}$ & $10487 \mathrm{c}$ & $7689 \mathrm{c}$ & $9088 \mathrm{~d}$ \\
\hline
\end{tabular}

Means within a column followed by the same letter are not significantly different at $P \leq 0.05$, by Duncan's multiple range test.

Table 2. Midpoint of harvest and harvest interval (5\% to 95\% of yield harvested) in 1996 and 1997 for nine red raspberry cultivars planted in 1994 at OSU-North Willamette Research and Extension Center, Aurora, Ore.

\begin{tabular}{|c|c|c|c|c|}
\hline \multirow[b]{2}{*}{ Cultivar } & \multicolumn{2}{|c|}{1996} & \multicolumn{2}{|c|}{1997} \\
\hline & $\begin{array}{l}\text { Midpoint } \\
\text { harvest }\end{array}$ & $\begin{array}{l}\text { Harvest interval } \\
(5 \% \text { to } 95 \%)\end{array}$ & $\begin{array}{l}\text { Midpoint } \\
\text { harvest }\end{array}$ & $\begin{array}{l}\text { Harvest interval } \\
\text { (5\% to } 95 \%)\end{array}$ \\
\hline Malahat & 7 July & 18 June-5 Aug. & 20 June & 10 June-8 July \\
\hline Willamette & 5 July & 18 June-23 July & 26 June & 17 June-15 July \\
\hline Chilliwack & 7 July & 18 June-5 Aug. & 26 June & 17 June-15 Aug. \\
\hline Chilcotin & 7 July & 18 June-5 Aug. & 1 July & 17 June-15 July \\
\hline Comox & 7 July & 18 June-5 Aug. & 1 July & 17 June-15 Aug. \\
\hline Tulameen & 12 July & 26 June-5 Aug. & 1 July & 20 June-21 July \\
\hline Meeker & 7 July & 26 June-5 Aug. & 8 July & 20 June-21 July \\
\hline Kitsilano & 15 July & 26 June-5 Aug. & 8 July & 20 June-28 July \\
\hline Coho & 12 July & 26 June-5 Aug. & 8 July & 26 June-21 July \\
\hline
\end{tabular}

Table 3. Mean scores for subjectively evaluated characteristics of nine red raspberry cultivars planted in 1994 at OSU-North Willamette Research and Extension Center, Aurora, Ore.

\begin{tabular}{lccccccccc}
\hline \hline & \multicolumn{2}{c}{ Cane vigor $^{2}$} & & \multicolumn{5}{c}{ Fresh fruit characteristics } \\
\cline { 2 - 6 } \cline { 5 - 8 } Cultivar & Primocane & Floricane & & Firmness & Color & Shape & Texture & Separation & Flavor \\
\hline Chilcotin & 6.8 & 7.0 & & 6.6 & 6.5 & 7.4 & 6.9 & 7.2 & 6.9 \\
Chilliwack & 8.3 & 8.8 & & 7.7 & 8.0 & 8.1 & 7.5 & 7.6 & 6.5 \\
Coho & 8.0 & 8.0 & & 7.8 & 7.3 & 7.9 & 7.6 & 7.5 & 7.9 \\
Comox & 8.3 & 8.3 & & 7.2 & 7.7 & 8.1 & 7.6 & 7.2 & 6.0 \\
Kitsilano & 8.0 & 7.7 & & 6.8 & 7.4 & 8.0 & 7.5 & 7.7 & -- \\
Malahat & 7.3 & 7.0 & & 6.7 & 7.8 & 8.5 & 7.8 & 7.3 & 8.1 \\
Meeker & 8.3 & 8.1 & & 6.8 & 7.5 & 7.6 & 7.8 & 7.9 & 7.3 \\
Tulameen & 7.4 & 7.5 & & 7.6 & 7.7 & 8.9 & 7.9 & 8.3 & 7.2 \\
Willamette & 7.5 & 8.1 & & 7.3 & 8.9 & 7.5 & 7.8 & 7.8 & 6.6 \\
Overall mean & 7.7 & 7.8 & & 7.2 & 7.6 & 8.0 & 7.6 & 7.6 & 6.7 \\
\hline
\end{tabular}

${ }^{2}$ Traits scored on a 1-9 scale, where 1 = poor vigor, soft fruit, very light colored, misshapen, very seedy, poor separation from the receptacle, and poor flavor, and $9=$ very vigorous, very firm, dark red, well formed, not seedy, separates easily from the receptacle, intense flavor, respectively.
1997), and 'Kitsilano' (Table 1). The fruit are attractive and conical in shape, but more similar in shape to 'Meeker' than 'Tulameen' (Table 3). Drupelets are consistent in size and shape, giving the fruit a very uniform appearance and reflecting good drupelet fertility. The fruit are bright red; not nearly as dark as 'Willamette' nor as light-colored as 'Chilcotin' (Table 3). Fruit flavor was rated excellent. Fruit are similar to 'Tulameen' in firmness and were rated the firmest of all compared cultivars (Table 3). The combination of firmness, flavor, and bright red, nondarkening color suggests that 'Coho' should be excellent for the fresh market. 'Coho' has not been tested for suitability to mechanical harvesting, but in subjective evaluations based on ease of separation, it seems similar to 'Chilliwack', which is considered to be easily mechanically harvested (Table 3 ).

In IQF evaluations by an industry group in 1994 (Yorgey and Farkas, 1995), the cultivars could not be separated by statistical analysis for the traits evaluated. In comparing the preference histograms for 'Coho' and 'Meeker', 'Coho' had lower scores for color and higher scores for appearance, flavor, sweetness, sourness, firmness, and overall scores. However, two evaluators ranked 'Coho' very low for all traits, suggesting that either there were some very poor samples or two evaluators used very different standards than the others in the group. While 'Coho' is not envisioned as a processing cultivar, growers have reported that it can yield a very high percentage (up to $80 \%$ ) of IQF quality fruit when processed (P. Miller, personal communication)

One of the most outstanding characteristics of 'Coho' is its late ripening when there are almost no other cultivars with ripe fruit (Table 2). It is slightly later than 'Tulameen' in most years and ripens with or is slightly earlier than 'Kitsilano'. It has been observed that 'Coho' maintains excellent fruit quality from the beginning to the end of the harvest season.

'Coho' primocanes and floricanes are vigorous, but not excessively so (Table 3). Canes are similar to 'Malahat' for spines that are primarily limited to the basal portion of the cane. 'Coho' produces a moderate number of canes with medium thickness. Fruiting laterals range from moderate to long in length and are strongly attached. Fruit is well-spaced along these laterals so that fruit accessibility is good.

Cold hardiness of 'Coho' has not been determined. However, the winter of 1995-96 was a reasonable test winter with -11 to -12 ${ }^{\circ} \mathrm{C}$ on several nights during the first week of February. The following spring, there was no obvious winter injury to the flower buds or canes.

Under a minimal spray program of dormant fungicides only, 'Coho' has shown no noteworthy damage from fungal diseases such as phytophthora root rot (Phytophthora fragariae var. rubi Wilcox and Duncan), spur blight [Didymella applanata (Niells) Sacc.], cane botrytis (Botrytis cinerea Pers. ex Fr.), and cane spot (Elsinoe veneta Burh.), which are commonly present in our plots. 'Coho' 
often avoids preharvest botrytis fruit rot $(B$. cinerea) because it ripens late, during dry weather. 'Coho' has tested positive for the common strain of raspberry bushy dwarf virus (RBDV) in the field, but it is unknown how quickly it becomes infected.

The outstanding characteristics of 'Coho' are its high yield, bright-red and firm fruit, and its late-ripening season. It is expected to do well where other red raspberries developed in the Pacific Northwest are adapted and is recommended primarily for fresh-market production.

\section{Availability}

'Coho' nuclear stock has tested negative for tomato ringspot, raspberry bushy dwarf, and tobacco streak viruses by enzyme-linked immunosorbent assay and has indexed negative on grafting to $R$. occidentalis L. 'Coho' is not patented. However, when this germplasm contributes to the development of a new cultivar, hybrid, or germplasm, it is requested that appropriate recognition be given to the source. Further information or a list of nurseries propagating 'Coho' is available on written request to C.E.F. The USDAARS does not have commercial quantities of plants to distribute. In addition, genetic material of this release has been deposited in the National Plant Germplasm System, accession number CRUB 2002, where it will be available for research purposes, including development and commercialization of new cultivars.

\section{Literature Cited}

Daubeny, H.A. 1987. 'Chilliwack' and 'Comox' red raspberries. HortScience 22:1343-1345.

Daubeny, H.A. 1997. Raspberry. In: W.R. Okie (ed.). Register of New Fruit and Nut Varieties Brooks and Olmo List 38. HortScience 32:785-805.

Daubeny, H.A. 1999. Raspberry. In: W.R. Okie (ed.). Register of New Fruit and Nut Varieties List 39. HortScience 34:181-205.

Daubeny, H.A. and A. Anderson. 1991. ‘Tulameen’ red raspberry. HortScience 26:1336-1338.

Finn, C.E., F.J. Lawrence, G. Langford, P. Moore, B. Yorgey, and B.C. Strik. 2001. 'Lewis' red raspberry. HortScience 36:1155-1158.

Moore, P.P. and H.A. Daubeny. 1993. 'Meeker' red raspberry. Fruit Var. J. 47:2-4.

Yorgey, B. and D. Farkas. 1995. Evaluation of processing quality of advanced caneberry breeding selections. 1994-95 Reports to the Agr. Res. Foundation for the Oregon Raspberry and Blackberry Comm. 